\title{
AS FEMINISTAS E A DIVERSIDADE DAS ALTERNATIVAS REPUBLICANAS
}

\author{
Carla Cecília Rodrigues Almeida
}

\author{
José Antônio Martins
}

\begin{abstract}
RESUMO
O artigo analisa a aproximação crítica de algumas feministas ao republicanismo e explora a hipótese de que tal aproximação expressa importantes pontos de contato com a vertente republicana popular. Com base em autores clássicos e adotando um critério específico para abordar a diversidade constitutiva do republicanismo, definimos os contornos daquela vertente e a da que lhe serve como contraponto: a vertente aristocrática. Nossa hipótese fundamenta-se, de um lado, na análise das críticas feministas a algumas formulações correntes que em alguma medida compartilham do ideal republicano de que a sociedade contemporânea necessita criar um sentido renovado para a vida pública. Por outro lado, fundamenta-se nas próprias propostas particulares que elas elaboram para apropriar-se daquele ideal. Essa análise possibilita-nos sugerir que as preocupações que caracterizam a vertente republicana popular oferecem fontes mais promissoras para que se possa combinar o ideal de revitalização da esfera pública com as demandas por justiça. A partir desse foco, salientamos as contribuições que as feministas têm fornecido à teoria democrática.
\end{abstract}

PALAVRAS-CHAVE: teoria feminista; republicanismo popular; republicanismo aristocrático; teoria democrática.

\section{INTRODUÇÃO}

Num artigo publicado originalmente em 2000, Anne Phillips (2004) propôs-se a avaliar as possibilidades de aliança entre o feminismo e o republicanismo. Considerando as convergências e as divergências existentes entre as duas correntes, a autora concluiu ser mais adequado para as feministas uma apropriação suficientemente prudente daquele. Dentre as várias justificativas que apresentou para sustentar essa posição, Phillips afirmou que as feministas compartilham da preocupação tipicamente republicana com a revitalização da esfera pública do mesmo modo que nutrem críticas, tal como os republicanos, às formulações liberais que restringem a política à competição de grupos de interesse e ao governo representativo. Entretanto, analisa Phillips, as feministas não concordam com determinadas concepções republicanas que, em nome do "bem-comum" ou dos "interesses gerais", tendem a produzir uma visão homogênea de sociedade e a ignorar o problema do conflito de interesses.

Nosso argumento é que essa aproximação crítica das feministas com o republicanismo possibilita-nos chamar a atenção para as distintas vertentes que o constitui, cujas origens e trajetórias reportam-nos a alguns autores clássicos do pensamento republicano. Sem a pretensão de desconsiderar outras possibilidades analíticas face à complexidade e variedade dessa tradição de pensamento político, adotamos um foco particular para abordar e definir aquelas distinções. Propomos, então, que é possível identificar naqueles autores a presença de dois modelos de república: um centrado na preocupação com a estabilidade política e com a coesão social; outro que não apenas valoriza o conflito, mas entende-o como fonte da vitalidade das instituições políticas. Denominamos aristocrático o primeiro modelo, posto que as preocupações que lhe são características requerem mais exigências para a participação política, ou seja, elas prescrevem critérios de excelência como condição para o exercício da cidadania. O segundo, denominamos popular, dado que suas preocupações deslocam a centralidade da exigência da excelência cidadã e têm como ponto nevrálgico a defesa de uma maior porosidade das instituições políticas.

Considerando o debate contemporâneo instituído pela retomada dos estudos republicanos, caracterizada por alguns como Republican Revival, e mais particularmente os reflexos que 
ela produziu no debate a respeito da democracia, procuramos mostrar nesse artigo os pontos que aproximam as feministas da fonte republicana popular. Para isso, vamos basear-nos, de um lado, nas críticas que elas fazem a certas formulações correntes que de algum modo incorporam ideais republicanos e, de outro, nas suas próprias sugestões de incorporação daqueles ideais. Cabe esclarecer, desde já, que não é nossa intenção julgar propriamente a pertinência daquelas críticas. O nosso esforço restringir-se-á a indicar que elas expressam insatisfações com as preocupações que caracterizam a vertente republicana aristocrática e pontos de aproximação com a popular.

Para desenvolver esse argumento, estruturamos o artigo em três partes. Na primeira, exploramos os traços contextuais do encontro das preocupações feministas com as preocupações tipicamente republicanas, situando-os no âmbito mais amplo da retomada dos estudos sobre o republicanismo e seus reflexos na teoria democrática. Na segunda parte, recuperamos os modelos de república defendidos por alguns autores republicanos clássicos a fim de mostrar suas correspondências com duas vertentes distintas de republicanismo. Finalmente, analisamos algumas considerações feministas a respeito da necessidade de combinar o ideal de revitalização da esfera pública com a projeção de instituições mais porosas ao dissenso e exigentes quanto à justiça, mostrando, assim, suas aproximações com as preocupações que são características do republicanismo popular.

\section{ENCONTROS ENTRE PREOCUPAÇÕES FEMINISTAS E REPUBLICANAS}

Nas décadas de 1960 e 1970, o movimento feminista, ao lado de uma diversidade de outros movimentos sociais, contrapôs as limitações da democracia liberal às potencialidades de transformação que portariam os formatos organizativos associados à democracia participativa. Entretanto, neste período, as formulações teóricas das feministas estavam centradas, em larga medida, na análise das dimensões propriamente políticas das relações cotidianas e privadas, bases sobre as quais se lançavam as exigências da democracia para os mais variados e diversificados espaços e relações sociais. Desse modo, os questionamentos endereçados à democracia liberal não se desdobravam em elaborações teóricas substantivas a respeito das instituições políticas propriamente ditas, mas em análises que procuravam tornar visíveis a presença da política e do poder nos lugares costumeiramente identificados com o mundo privado. Conforme assinala Phillips: "La relación entre estos principios organizativos [práticas de assembléias] y los principios que deberían gobernar la política en general no era una de las prioridades urgentes aunque, bajo el lema genérico de 'lo pessoal es político', las feministas desarollaron un análisis que consideraba que el poder era algo omnipresente y que ressaltaba la importancia de la democracia en todos los ámbitos de la vida" (PHILLIPS, 1996, p. 79).

Ao decorrer das décadas seguintes, as preocupações teóricas das feministas deslocaram-se, de maneira mais incisiva, para as instituições e para o tema dos fundamentos que garantiam, a despeito da vigência de direitos formais, a perpetuação da exclusão ou da sub-representação de determinados grupos no sistema político. Assim, questionamentos foram endereçados à pretensa universalidade contida no ideal de cidadania presente na tradição do pensamento ocidental que, arraigada nas instituições políticas, estaria, em realidade, fortemente implicada com a produção daquelas exclusões. Esse foi um período também em que o ativismo político feminista reivindicou um aumento da presença das mulheres nas estruturas decisórias (SQUIRES, 2001).

A produção feminista sobre aqueles temas revelou dissensos importantes que expressam a própria diversidade desse campo. Para além das várias posições nutridas quanto à maneira de abordar-se as instituições na sua relação com as exclusões de gênero, um dos dissensos presentes dizia respeito ao próprio deslocamento das preocupações feministas em direção às instituições políticas. De acordo com Nash (2001), essa perspectiva alertava para os possíveis custos advindos da excessiva atenção às lutas institucionais, salientando a necessidade de recuperar a importância das intervenções na sociedade civil como condição de avanço das lutas do movimento feminista. Entretanto, pode-se afirmar que aquela produção não deixou dúvidas quanto à necessidade manifestada por algumas de suas vertentes no sentido de recuperar as especificidades da atividade política e da esfera pública. Para algumas, a orientação do momento anterior, fundada na concepção de que "o privado é também político", deixara 
nublada e opaca a natureza própria da esfera pública. Desse modo, reconhecendo os ganhos, mas apontando para os riscos que aquela orientação legou à teoria feminista, Anne Phillips assim analisou a relevância que passou a ter a noção de esfera pública nesse campo: "When feminists claimed the personal as political, they were contesting the passivity that treated relationships between the sexes as so determined by history or biology that no one could seriously hope to fashion them in another way. In doing so, they drew attention to the power relations that shape the most intimate fabric of private life. [...] But the questioning of distinctions between public and private has been said to lead to an over-politicization of personal and familial life, and a corresponding depoliticization of public life by wooly notions about emotion or empathy or care. [...] Literal interpretations of 'the personal is political' have been widely criticized in recent years, and for many feminists, the more careful delineation of what is and isn't political has combined with a growing interest in the analysis of the public sphere"1 (PHILLIPS, 2000, p. 102).

Nesse contexto, a coletânea organizada por Joan Landes em 1998, intitulada "Feminism, the Public and the Private", forneceu um panorama da produção feminista a respeito das preocupações concernentes à esfera pública. Mostrou também o quanto, a partir delas, o pensamento de Hannah Arendt, até então muito criticado por postular uma dicotomia entre o público e o privado, tornava-se referência importante para o diálogo. Do mesmo modo, as feministas dialogaram com as análises de Jürgen Habermas sobre a esfera pública burguesa, ainda que para expressar seus incômodos quanto a elas. Segundo Fraser (1993),

\footnotetext{
1 "Quando as feministas reivindicaram o pessoal como político, estavam contestando a passividade que tratava os relacionamentos entre os sexos como determinados pela história ou biologia, de modo que ninguém poderia seriamente esperar apresentá-los de outro modo. Fazendo-o, atraíram a atenção às relações de poder que moldam a estrutura mais íntima da vida privada. [...] Mas o questionamento das distinções entre público e privado, diz-se, tem conduzido a uma sobre-politização da vida pessoal e familiar e a uma correspondente despolitização da vida pública por noções confusas de emoção, empatia ou cuidado. [...] Interpretações literais do 'pessoal é político' têm sido amplamente criticadas nos anos recentes e, para muitas feministas, a delineação mais cuidadosa do que é e não é político tem-se combinado com um interesse crescente na análise da esfera pública"
}

por exemplo, Habermas não teria conferido importância devida, em sua análise, às exclusões de gênero, classe e etnia sobre as quais a esfera pública burguesa construiu-se historicamente, como também não teria levado em conta a importância da emergência, face àquelas exclusões, de uma multiplicidade de outras esferas públicas, denominadas por ela contrapúblicos, que foram fundamentais para a própria elaboração de práticas e discursos alternativos e contestatórios pelos grupos excluídos.

É necessário registrar um segundo motivo pelo qual a esfera pública ganhou estatuto de preocupação teórica entre as feministas. Ele foi o resultado de uma avaliação por elas empreendida a respeito das políticas de identidade, fortemente preconizadas por uma importante variante do movimento e da teoria feminista nas décadas de 1980 e 1990. Fundamentada nos questionamentos teóricos a respeito da pretensão universalista do conceito de cidadania, a demanda pelo reconhecimento das diferenças alimentou a agenda de vários movimentos, para além do feminista, em distintos contextos. A crítica ao caráter de gênero constitutivo dos conceitos de cidadania e democracia presentes na tradição do pensamento moderno ocidental colocava, nessa agenda, a necessidade de valorizar o reconhecimento das diferenças. Para muitas, tal reconhecimento era estratégico para a construção de uma identidade positiva das mulheres e para a formulação de um projeto mais amplo de mudanças sociais.

Entretanto, os movimentos pró-política de identidade abriram espaço para a percepção da existência de uma multiplicidade de outras diferenças. Eles mostraram que o gênero estava longe de possuir a centralidade afirmada pelas feministas e que em seu nome um conjunto de outras demandas, necessidades ou interesses podiam ser silenciados. Como analisa Squires (2001), a explosão da demanda pelo reconhecimento das diferenças questionou o "ser universal feminino" então afirmado, mostrando que ele estava fortemente baseado em demandas advindas de uma experiência feminina situada: a de mulheres brancas, ocidentais, heterossexuais e de classe média. Tal questionamento gerou uma crise que colocou em suspeita a própria viabilidade de um movimento feminista, como assim analisou Linda Zerilli: "The critique of the feminine subject as the basis for feminist politics came, in the course of the 1990s, to generate a sense of political crisis. If feminism 
no longer had a 'subject' in whose name it could speak, critics argued, how could one speak of a movement called feminism? How can one make claims in no one's name? And what distinguishes feminism from, say, political movements based on issues of class, race, or ecology? Why speak of feminism at all?"2 (ZERILLI, 2006, p. 113114).

Segundo a autora, as políticas de identidade combinadas com a ênfase na análise da formação da subjetividade teriam afastado as feministas da preocupação de formular um entendimento mais robusto sobre as questões concernentes à ação coletiva e à esfera pública, vistas como condição para a construção de uma plataforma de lutas orientadas à promoção de justiça econômica e política. Elas teriam perdido de vista, em larga medida, as preocupações legítimas presentes em autores clássicos a respeito da vida em comum e da necessidade de princípios mais amplamente compartilhados, sem os quais não se pode chegar a acordos sobre critérios de justiça.

Assim, procurando superar a fragmentação resultante das políticas de identidade, na mesma medida em que deslocavam o foco das "questões" e "problemas" exclusivos às mulheres para a relação daqueles problemas com a vida em comum, algumas feministas aproximaram-se da tradição de pensamento republicano (PHILLIPS, 2004). Tomando um artigo de Mary Dietz (1999) como referência, publicado originalmente em 1987, aquela aproximação parecia justificar-se pela idéia de que o republicanismo oferecia uma base mais adequada para a recuperação da natureza específica da atividade política, tarefa da qual dependia, na sua visão, a própria elaboração de um projeto democrático alternativo.

De fato, o artigo de Dietz é um exemplo particularmente ilustrativo da inclusão contemporânea, pelo campo feminista, das preocupações e da pró-

\footnotetext{
2 "A crítica do sujeito feminino como a base para a política feminista veio a gerar, no curso da década de 1990, um senso de crise política. Se o feminismo não mais tinha um 'sujeito' em cujo nome pudesse falar, diziam os críticos, como alguém poderia falar de um movimento chamado feminismo? Como pode alguém fazer reivindicações em nome de ninguém? E o que distingue o feminismo de, digamos, movimentos políticos baseados em questões de classe, raça ou ecologia? Por que falar de feminismo, de qualquer modo?".
}

pria linguagem tipicamente associadas ao republicanismo. Para ela, as feministas deveriam ir além da reivindicação de oportunidades iguais nas estruturas políticas e econômicas, já que isto seria insuficiente para a própria construção de conceitos alternativos de cidadania e de política democrática. Nesse sentido, entendia que a tarefa do feminismo estava em reinventar a política democrática segundo as exigências da atividade cívica e do auto-governo participativo, superando, assim, o modelo do governo representativo. Ao defender a alternativa republicana, Dietz apontou os limites de outras variantes do feminismo para a elaboração de um conceito de política que tivesse como base o compromisso coletivo com a participação dos cidadãos e cidadãs na resolução dos assuntos de sua comunidade. Considerando as elaborações das feministas marxistas, por exemplo, ela argumentou que nelas a liberdade não era tratada como um valor de natureza propriamente política, mas restritamente econômica. Por outro lado, a perspectiva maternalista, ao valorizar a esfera privada e sua suposta ética feminina constitutiva, subtraia da cidadania o vínculo eminentemente político que esta supõe e que diz respeito à igualdade entre os indivíduos, e não ao cuidado, característico das relações entre mães e filhos.

A preocupação de fundo que Dietz expressa em relação a essas variantes é que elas não forneceriam, na sua visão, referências para a compreensão da especificidade da esfera pública, dos vínculos propriamente políticos existentes entre os indivíduos. Ela propôs que a democracia fosse compreendida, sobretudo, como a liberdade positiva para debater e decidir, conjuntamente, assuntos públicos. De acordo com sua avaliação, as feministas não deveriam conceber a cidadania como atributos de indivíduos precavidos estranhos entre si, tal como o liberalismo, nem como íntimos carinhosos, tal como as maternalistas. As feministas deveriam comprometer-se com uma cidadania democrática que não deveria confundir-se nem com a política liberal de grupos de pressão e governo representativo, nem com a idéia de que depois da vitória ou da derrota, a respeito de um assunto, terminou o jogo e podemos "voltar para casa”, como postulavam, na sua avaliação, as marxistas (idem, p. 23). Nessa medida, ela defendeu que a tarefa de revitalizar a cidadania democrática seria especialmente adequada ao empreendimento feminista, já que, na sua segunda 
onda, os movimentos feministas haviam valorizado a democracia de base, as reuniões espontâneas abertas aos debates e as estruturas não hierárquicas de organização. Para cumprir essa tarefa, as feministas precisavam superar o "mulherismo" e o seu artigo sugere, então, o diálogo com autores republicanos, entre os quais cita Hannah Arendt, J. G. A. Pocock e Michael Sandel.

É necessário lembrar que essas preocupações e sugestões formuladas por Dietz e a própria aproximação de outras feministas com os ideais republicanos foram constitutivas - ao mesmo tempo em que receberam as influências - do contexto mais amplo marcado pela retomada dos estudos republicanos ou, como qualificam Ovejero, Martí e Gargarella (2004), pelo giro republicano do debate contemporâneo. Ainda que panoramicamente, cumpre mencionar algumas das fontes irradiadoras desse giro, bem como os traços mais gerais dos problemas que o instigaram.

Assim, uma referência fundamental foram os trabalhos da Escola de Cambrigde sobre as fontes republicanas da Independência americana, cujo autor representativo é J. G. A Pocock. Seguindo pistas abertas por trabalhos anteriores, sua análise questionou a leitura que relacionava o ambiente revolucionário americano da época da independência às influências da filosofia liberal e mostrou a presença decisiva naquele contexto das idéias republicanas que haviam transitado da Antigüidade ao Renascimento italiano, chegando até o mundo anglo-saxão. Seus estudos instigaram e abriram novas perspectivas de pesquisa sobre o pensamento republicano, particularmente sobre o republicanismo renascentista, cujos desdobramentos alimentaram um rico debate a respeito do conceito da liberdade republicana.

Expoentes desse debate, os trabalhos de Skinner (2004) e Pettit (1999; 2004) questionaram a dicotomia entre liberdade positiva, identificada com o republicanismo, e a liberdade negativa, com o liberalismo, tal como estabelecida por Berlin (2002). Guardadas as devidas nuances e as variadas ênfases das suas concepções, aqueles autores argumentaram que o núcleo distintivo da liberdade republicana não estaria na valorização da participação em si, tal como o conceito de liberdade positiva postulava. A participação aparece na definição de liberdade republicana desses dois autores não como sua essência, mas como instrumento necessário para garanti-la. Como ana- lisa Silva (2008), Skinner e Pettit enfatizam o estatuto jurídico da liberdade republicana baseandose nas idéias e nas instituições da república romana e no pensamento de Maquiavel, que encontrou naquelas suas principais fontes de reflexão. Nessa medida, buscam-se distinguir do republicanismo que tem como referência central o modelo das polis grega, cuja expressão seria encontrada nos trabalhos de Hannah Arendt e na reflexão de autores comunitaristas, como Michael Sandel ${ }^{3}$.

O comunitarismo está relacionado, por vez, a outro debate que foi constitutivo da retomada dos estudos republicanos e que transcorreu principalmente na década de 1980 , no contexto norte-americano. Tal debate foi motivado pela obra de Jonh Rawls sobre a justiça. Autores como Michael Sandel reivindicaram um republicanismo de corte comunitarista, com sua ênfase na comunidade enquanto fonte das identidades individuais e do "bem-comum", como alternativa à hegemonia liberal do período, da qual a própria repercussão obtida pela obra de Rawls era evidência. A reação dos comunitaristas àquela obra, que teria se fundamentado numa ontologia atomista, enfatizava que nenhuma sociedade, nem mesmo as sociedades liberais e pluralistas contemporâneas, poderia sobreviver sem possuir e preservar, para usar os termos de Hirschman (1995), um grau suficiente de "espírito de comunidade", capaz de cimentar os vínculos entre os indivíduos e garantir, assim, a unidade do corpo político. Outra crítica que os comunitaristas endereçaram a Rawls diz respeito à sua defesa, tipicamente liberal, de que o Estado não poderia legitimamente nutrir o ideal de perseguir um "bem comum" dada a pluralidade das sociedades contemporâneas. Quanto a isso, os comunitaristas alegaram que defender a tolerância, como propunham os liberais, já indicaria a defesa de um ideal de "bem-comum" e, portanto, a neutralidade liberal seria uma falácia. Por outro lado, como contraponto às formulações de Skinner e Pettit, os comunitaristas concebem a participa-

\footnotetext{
3 Em seu trabalho, Silva (2008) tanto nos permite compreender o conjunto mais amplo de questões vinculadas ao debate contemporâneo sobre o conceito de liberdade, quanto nos ajuda a entender os esforços de Skinner e Pettit para diferenciar suas concepções de liberdade republicana da concepção republicana ateniense, fundada em referência à polis grega, e da liberal.
} 
ção política como a essência da liberdade republicana, já que esta promoveria a identificação comunitária dos indivíduos, aspecto que lhes parecem demarcar importantes distâncias entre os republicanos e os liberais.

Embora a caracterização apresentada desses estudos e debates seja insuficiente para cobrir a amplitude e a riqueza das questões que envolveram, para o que nos interessa aqui basta apontar que, no seu conjunto, eles serviram de interlocutores ou preparam o terreno para várias e distintas reflexões filosóficas e políticas que vieram colocando o problema do modo de inserção do cidadão na esfera pública no centro dos seus diagnósticos sobre os limites da experiência democrática contemporânea. De modo geral, aquelas reflexões criticaram o que lhes pareciam ser as características mais salientes daquela experiência, como a restrição do exercício da cidadania ao ato de votar e a fragilização dos vínculos e compromissos dos cidadãos com os assuntos públicos. Nesse contexto, a concepção que se tornou hegemônica a partir de Joseph Schumpeter serviu como um forte contraponto para muitas reflexões. Denominada democracia liberalpluralista, seus princípios foram reproduzidos, com nuances e diferenças mais ou menos significativas, por um conjunto diverso de autores. Tal concepção, como alegaram os críticos, teria restringido a democracia a um método de escolha de governantes e competição de elites e, a própria política, à mera agregação de preferências particulares, esvaziando ou diminuindo-lhe o sentido da soberania popular e da vida em comum.

Assim, as preocupações de Dietz mencionadas anteriormente e suas apostas republicanas são constitutivas desse giro republicano, cujos ecos fizeram-se presentes na teoria democrática ${ }^{4}$. Nesse contexto, foi marcante a influência do modelo de democracia deliberativo, que tem nas análises de Jürgen Habermas sobre a esfera pública uma fonte fundamental de formulação. Embora a concepção de esfera pública de Habermas distancie-se em aspectos importantes da concepção republi-

\footnotetext{
4 Para uma análise das teorias democráticas que circulam no debate contemporâneo e que de algum modo são críticas ao modelo liberal nas suas vertentes pluralista e elitista, consultar, entre outros, Miguel (2005).
}

cana clássica de Hannah Arendt, ela conserva proximidade em determinados aspectos com os ideais republicanos. Tal modelo postula que o núcleo vital da democracia estaria, por exemplo, nos processos de discussão pública livre a todos, nos quais, em condições ideais de igualdade e liberdade de fala, os cidadãos poderiam, pela argumentação racional, chegar a consensos sobre os problemas comuns. A ênfase desse modelo está, portanto, na capacidade do diálogo racional promover entendimentos públicos em condições ideais de liberdade e igualdade.

Cumpre notar que outro modelo que passou a circular nesse debate, o denominado participativo, tem na feminista Carole Pateman (1992) sua referência fundamental. Em "Participação e Teoria Democrática", de 1970, ela dialoga criticamente com a concepção liberal-pluralista, que teria não apenas reduzido o papel da participação nas sociedades modernas como também a teria concebido como implausível e indesejada nesse contexto. Esse modelo diferencia-se do anterior pela sua maior ênfase nos resultados pedagógicos da participação e nos aspectos referentes aos arranjos institucionais que poderiam promovê-la.

Outras feministas também se tornaram importantes na discussão sobre concepções de democracia alternativas à liberal. Como exemplo, dialogando criticamente com os autores da democracia deliberativa, Young (2001) propõe o que denomina concepção comunicativa de democracia. De acordo com ela, tal concepção possibilitaria elaborar de maneira mais satisfatória o núcleo que distingue as concepções fundamentadas no debate público das que são fundamentadas na agregação de interesses, ou seja, permitiria compreender como as preferências privadas podem ser transformadas mediante aquele debate, com a finalidade da construção de acordos públicos.

Retomaremos mais a frente às idéias de Young e às suas críticas ao modelo deliberativo, já que, por ora, desejamos apenas chamar a atenção para o que esperamos ter deixado sugerido: o movimento de retorno ao republicanismo comportou múltiplas facetas e divergências no seu interior. Assim, se a alternativa republicana oferece um horizonte mais rico e robusto por meio do qual podemos elaborar um ideal de democracia, por outro lado, tal horizonte presta-se a distintas formas de apropriação. 


\section{REPUBLICANISMO ARISTOCRÁTICO E POPULAR: UMA BREVE INCURSÃO NOS MODELOS DOS AUTORES CLÁSSICOS}

De forma recorrente, a bibliografia tem traduzido a diversidade intrínseca ao republicanismo em termos das clivagens existentes entre suas vertentes ateniense e romana, também identificadas, respectivamente, como um republicanismo comunitário e liberal (CRISTI, 2003; ELIAS, 2008). Os diferentes entendimentos do que caracterizaria o conceito de liberdade republicana e, portanto, demarcaria suas fronteiras em relação ao conceito de liberdade liberal, encontram-se na base da definição daquelas clivagens. A bibliografia costuma identificar, entre outros, Hannah Arendt e os autores comunitaristas com a vertente ateniense e Maquiavel, Skinner e Pettit, com a neoromana (CRISTI, 2003; ELIAS, 2008; SILVA, 2008).

Optamos aqui por outro foco de abordagem e distinção das vertentes republicanas que, se mantém conexões com o debate sobre a liberdade, possibilita-nos, entretanto, entrar mais diretamente em um problema que é central nas preocupações feministas, que é o da composição e o grau de porosidade das instituições ${ }^{5}$. Desse modo, esse foco parece-nos oferecer uma ponte mais promissora para analisar as relações entre as preocupações feministas e a discussão sobre os ideais republicanos. Trataremos, assim, as distinções intrínsecas ao republicanismo em termos de uma vertente aristocrática, caracterizada pela maior exigência quanto às condições de inclusão política face sua preocupação com a estabilidade, e outra popular, preocupada, sobretudo, com a porosidade das instituições mediante sua valorização do conflito.

Para compreender a origem e a trajetória daquelas vertentes, é importante lembrar que os ideais republicanos resultaram do legado de uma discussão que perpassou distintos momentos e contextos históricos nos quais a república ou o regi-

\footnotetext{
5 É importante esclarecer que a escolha desse critério para analisar as distinções do republicanismo limita nossas possibilidades de incluir na discussão, daqui por diante, autores contemporâneos, como Pettit e Skinner, cujas formulações estão, em larga medida, centradas no conceito de liberdade. A análise desses autores exigiria um esforço de caracterização dos republicanismos que não é o que nos propomos realizar aqui.
}

me misto foram defendidos como a forma de governo mais adequada para vida em sociedade. Tal discussão desenrolou-se desde a Grécia Antiga, passando pela Roma republicana, pelo humanismo cívico do Renascimento italiano, chegando até alguns contextos revolucionários modernos - como o da Inglaterra revolucionária, o da luta pela independência das colônias da América do Norte, o da Revolução Francesa e o da luta pela independência dos países latino-americanos.

Em todos esses momentos, as reflexões sobre a instalação da república como regime distinto da monarquia, ou como superação do governo de um só, foram marcadas pela preocupação com a composição das esferas decisórias e, portanto, com a definição do papel que caberia aos diversos segmentos da sociedade na vida pública. Tomando como exemplo alguns autores que foram importantes na elaboração daquelas reflexões, é possível perceber não apenas que eles responderam distintamente àquela preocupação, como também se pode identificar nuances e alterações significativas sobre o assunto num mesmo autor.

Como exemplo, Aristóteles, no livro III da obra "Política", analisa as variadas formas de governo que poderiam resultar das distintas maneiras de se compor as esferas decisórias, considerando a combinação do critério de qualidade (virtude ou retidão, vício ou desvio) e da quantidade (governo de um só, de alguns e de muitos). Entretanto, no livro IV, é possível identificar uma quebra em sua argumentação, já que neste o autor preocupase em definir qual seria a melhor forma de governo entre todos e não toma mais os critérios adotados no livro III, passando a ter em vista os cidadãos efetivamente existentes, ou seja, o substrato material ou hipokeimenon da polis. Para responder a essa pergunta, toma como ponto de partida a idéia de que em toda e qualquer polis há dois grandes segmentos políticos: uma parcela, em geral diminuta e possuidora de riqueza, denominada oligarquia, e outra, geralmente predominante e detentora de liberdade, mas sem riqueza, caracterizada como democracia [ou o poder (cratos) do povo (demos), em uma tradução mais livre].

O filósofo conclui que o ideal seria um governo que combinasse a virtude (areté), a riqueza (oligarquia) e a liberdade (democracia), forma essa conhecida como aristocracia, ou seja, um governo fruto da areté, logo um cratos-areté. Ele consi- 
dera, entretanto, que esse ideal é impossível, visto que no conjunto dos cidadãos (politikós) não há uma identidade entre o bom-homem e o bompolítico. Por isso, para Aristóteles, a solução seria a instalação de um regime que congregasse proporcionalmente as parcelas democráticas e oligárquicas da polis, ou seja, um regime que misturasse proporcionalmente a liberdade e a riqueza. Tal forma de governo (politéia mixeis) será resultado do modo como se distribui e se compõe o substrato material da polis, não sendo possível, pois, uma conformação padronizada e única para toda e qualquer cidade. Essa forma de governo misto deveria ter como fundamento as parcelas medianas da polis. Diz-se mediana e não média, visto que a primeira não corresponde à média aritmética dos políticos, critério este que não satisfaz a proporcionalidade exigida para o regime. Sobre essa parcela mediana, o regime encontraria maior estabilidade e atenderia a uma justiça relativa (e não absoluta). A politéia resultante é, pois, um mistura (mixis) proporcional de oligarquia e democracia, e um mediana (meson) também proporcional aos diversos segmentos da polis.

Nota-se, assim, que, em Aristóteles, o governo de fato, e não aqueles idealizados e descritos no livro III, deveria ser formado a partir de uma mistura e uma mediania resultante das duas parcelas mais significativas da cidade por ele consideradas. A sua noção de mistura não é, pelo visto, uma composição das parcelas virtuosas das três formas de governo simples (governo de um só, governo de alguns, governo de todos), mas uma mistura relativa ao substrato material da polis. Mistura essa que pode ser, como declara o próprio filósofo, mais oligárquica em alguns casos, mais democrática em outros, mas nunca totalmente oligárquica ou democrática.

Avançando um pouco no tempo, em Políbio tem-se a equiparação da noção grega de politéia mixis - que, diga-se de passagem, não é somente aristotélica, mas também estava presente em outros filósofos gregos - com a res publica romana. O pensador, no livro VI de História, interrompe sua exposição sobre a história de Roma e passa a dissertar sobre as teorias da formas de governo, com destaque para o regime romano. $\mathrm{O}$ que se nota nesse escritor grego, que estava a serviço do governo romano, é a identificação do ordenamento político republicano romano com a teoria grega do governo misto. Conforme Nicolet (1973) e Sasso (1967), é por meio dessa reflexão polibiana que a república romana, conforme descrita no texto de História, é compreendida como a melhor realização do ideal de regime misto dos gregos. Contudo, agora acrescida de um dado central: a virtude militar do soldado romano, que ocupa grande parte de sua dissertação sobre os regimes no livro VI de História. Tal elemento pode ser identificado com a exaltação das virtudes políticas do cavaleiro romano, o varão (vir), membro de uma ordem eqüestre, logo aristocrática, mas também com o engajamento do cidadão (cives) comum que se torna soldado. O que se deve ressaltar é que essa equiparação polibiana entre a politéia mixis grega com a res publica romana seguir-se-á no mundo latino, o que permitirá aos autores do Renascimento italiano forjarem suas teorias republicanas a partir tanto das noções gregas de politéia mixeis do aristotelismo, quanto da noção de res publica da tradição latina ciceroniana (BLYTHE, 2005).

Já em Cícero encontramos outro exemplo de reflexão republicana que destaca o papel dos segmentos populares e aristocráticos. Conforme Lepore (1954), na obra do pensador romano verifica-se a defesa de dois modelos de repúblicas em momentos distintos de sua vida intelectual. Num primeiro, em seus escritos de juventude, nota-se a defesa dos segmentos aristocráticos ou patrícios como os elementos mais importantes na condução dos destinos da república. Em um segundo momento, verificável nos escritos de maturidade, particularmente em De Leggibus, De Officis e De Republica, opera-se uma ruptura com essa concepção aristocrática de república, na medida em que Cícero defende os populares ou plebeus, encarnados na defesa da noção do hominum bonum por oposição ao uir ou o varão, das formulações aristocráticas. Esse homem bom é simbolizado pelo cidadão soldado, aquele a quem se deve admirar por seu amor à pátria, visto que dá a vida por ela. Essa noção de homem bom é desenvolvida e passa a indicar, também, o cidadão comum, em geral o plebeu, que ganha um estatuto político em Cícero semelhante ao politikos grego (idem).

Essa explanação indica, assim, a preocupação dos pensadores antigos com a composição da república e também a presença predominante de duas possibilidades distintas para sua definição. Tal distinção estará presente também em outro momen- 
to profícuo do debate republicano, a saber: no contexto político do Renascimento italiano. Neste momento, como mostraram Gilbert (1977) e Pocock (1980), no bojo das discussões sobre o melhor modelo de república a ser adotado, dois modelos foram mobilizados: uma república de caráter aristocrático, simbolizada por Veneza, e uma mais acessível aos segmentos populares, exemplificada pela república florentina da virada do século XV para o século XVI, após a queda dos Médici e da instalação de um regime republicano. Tal debate polarizou, de um lado, autores como o veneziano Bernardo Brembo e os florentinos Bernardo Ruccelai e Francesco Guicciardini, que defendiam uma república de caráter aristocrático, e de outro, autores como Donato Giannoti e Nicolau Maquiavel que, ao contrário, elogiavam um modelo de república mais popular.

Talvez esse seja o maior legado do debate republicano do Renascimento italiano. Os pensadores desse período, em um contexto de disputa, acentuaram o núcleo distintivo dos modelos de república que defendiam". Divergência da mesma natureza fez-se presente ainda em outros momentos do pensamento político moderno, em autores como Rousseau, Kant e Montesquieu. Entretanto, como não se trata aqui de fazer uma "história" do republicanismo, mas de apontar essa divergência de posições no interior dos republicanismos, consideramos suficiente explorar os seus elementos a partir dos autores clássicos já mencionados.

Desse modo, cabe sublinhar que para os renascentistas que defendiam o modelo de Veneza, pareciam-lhes neste coabitar de modo harmonioso os três regimes simples exaltados pelos gregos: $i$ ) o governo de um só, representado pelo governante vitalício, o Doge; ii) o governo de alguns, representado pelos Conselhos Superiores, preenchidos por segmentos aristocráticos, os gentil-uomini; iii) o Grande Conselho, onde a população tomava parte nas decisões. Entretanto, é plausível supor que, na medida em que os próprios humanistas conheciam melhor os detalhes do funcionamento da república de Veneza, percebiam que essa imagem de governo ideal e perfeito era um mito, visto que ela estava controlada totalmente pela aristocracia ou os gentil-uomini, sem a participação efetiva da população.
Outro aspecto sempre exaltado na república de Veneza era a sua estabilidade. A ausência de conflito nos seus ordenamentos políticos rendeulhe, à época, a alcunha de república sereníssima. Assim, para os defensores de um governo republicano de caráter mais aristocrático, o predomínio desse grupo social justificava-se, via de regra, por suas qualidades ou excelências intrínsecas. Como vimos, mesmo no mundo grego, a própria compreensão de aristocracia derivava da noção de areté ("virtude" em grego), donde o governo aristocrático ser o governo dos virtuosos, dos homens dotados da excelência que aquela polis tinha em alta conta: se era uma sociedade de guerreiros, a aristocracia era composta pela elite guerreira, e assim por diante para sociedades predominantes de marinheiros, comerciantes etc. Ora, nesta tradição de pensamento político, depositar os destinos da cidade nas mãos dos homens considerados mais excelentes sempre foi entendido como a decisão mais sábia e inconteste. $\mathrm{O}$ que decorre desse raciocínio, como defendem vários pensadores gregos, romanos e mesmo boa parte dos cristãos medievais, é que essas qualidades morais precisavam ser exercitadas e desenvolvidas num outro momento que não os dos afazeres cotidianos, ou seja, naquele tempo do dia reservado ao ócio contemplativo. Evidentemente, essa oportunidade só seria possível para aqueles que dispusessem de tempo e riqueza, estando livres para o exercício das virtudes políticas.

Essa reflexão, que caracterizamos en passant, foi apropriada dos mais diversos modos por inúmeros pensadores políticos, mas conservou um elemento comum: a exigência da virtude ou excelência dos homens públicos, que implicava numa restrição de acesso à esfera política. No limite, essa é uma característica das concepções republicanas marcadas pelo signo aristocrático: $\mathrm{o}$ acesso ao poder e à participação está sujeito não à condição de pertencer ao corpo político, mas de comportar um elemento virtuoso que não é um atributo de todos os cidadãos. Como disse Aristóteles, não é comum a identificação entre o homem bom ou o prudente (phronimós) e o cidadão ou político (politikós) (ARISTÓTELES, 1998). Ao exigir-se, pois, virtude e excelência dos cidadãos para o seu ingresso nas esferas decisórias do poder político, exige-se automaticamente a composição de um governo virtuoso e restrito. 
Uma qualidade exaltada no modelo de república aristocrático, que está intimamente associada à sua defesa da cidadania virtuosa, é a ausência de conflitos políticos internos, o predomínio de uma certa pax socialis, que implicaria em maior durabilidade dos regimes. Como o governo está nas mãos daqueles que são os mais preparados para as decisões políticas, os demais grupos sociais não ambicionam o poder, logo, não se oferecem oportunidades para o surgimento de disputas políticas que acarretariam, nesta visão, divisão ou até dissolução do corpo político. Ademais, estando o governo sob o comando dos mais capazes para o exercício da política, os outros ficam livres para conduzir seus negócios, gerando uma perfeita harmonia. Para corroborar essa idéia, evocou-se o exemplo antigo de Esparta e o exemplo de Veneza e o contraexemplo da república romana, que se viu afogada nas guerras civis quando a plebe tentou tomar parte nos rumos da política. A longevidade dos dois primeiros casos e a rapidez com que se dissolveu o regime romano justificavam a idéia de que um governo comandado pela aristocracia seria mais estável e duradouro.

Dentre aqueles que defenderam outra forma de república, talvez o exemplo mais emblemático seja o de Maquiavel. Nos seus Discurso sobre a primeira década de Tito Lívio, encontramos um exemplo significativo de refutação desse modelo de república aristocrática e a defesa de uma república de caráter popular. Tomando como referência os 18 primeiros capítulos do livro, também conhecido como "O pequeno tratado sobre as repúblicas” (SASSO, 1967; GILBERT, 1977; MARTINS, 2007), encontramos os elementos centrais da crítica maquiaveliana ao modelo de república aristocrática e, ao mesmo tempo, a defesa de uma república de caráter mais popular. $\mathrm{Na}$ visão do Secretário florentino, ao contrário do que era argumentado, um regime aristocrata seria frágil, instável e sem força para a conquista. Como ele analisou em diversas passagens, Esparta e Veneza, longe de serem regimes fortes, estavam condenados a manter-se nos limites territoriais já definidos, não podendo se expandir sob o risco da ruína. Para ele, por não admitirem novos elementos no corpo político, essas repúblicas não tinham força política (MACHIAVELLI, 1984). Ademais, conforme sua definição clássica, nos grandes ou ricos verifica-se o interesse em dominar e, nos pobres, a vontade de não serem domi- nados, ou seja, o governo sob o comando único e exclusivo da aristocracia não redunda em liberdade, mas em dominação. Considerando a aparente estabilidade de Veneza, ele defendeu um regime calcado na inserção das parcelas populares na esfera decisória, ainda que isso acarretasse conflito. Na verdade, Maquiavel vai além, pois concebe o conflito político como força motriz de toda a vida da cidade. Como afirmou: "Direi que quem condena os tumultos entre os nobres e a plebe parece censurar as coisas que foram a causa primeira da liberdade de Roma e considerar mais as assuadas e a grita que tais tumultos nasciam do que os bons efeitos que eles geravam" (idem, p. 71). Para esse autor, a vitalidade das instituições romanas seria resultado do próprio fato de terem sido forjadas num contexto de conflitos políticos, resultando na criação dos tribunos da plebe.

Por isso, a força, a grande qualidade de uma república estaria, para Maquiavel, nos tumultos ou conflitos políticos, já que esses seriam a expressão do engajamento político das diversas parcelas de um Estado. A vitalidade de um Estado derivaria, para o filósofo, do quanto estaria aberto para todos os seus membros, e não somente a um diminuto grupo de aristocratas, ou, como disse Maquiavel, aberto apenas a não mais do que 40 ou 50 pessoas (idem, p. 105). Exposta a importância da disputa política para as repúblicas, ele mostra, então, como os poderes (Legislativo, Judiciário e Executivo), quando conformados por uma lógica mais aberta, seriam mais salutares e eficazes politicamente. E, por fim, Maquiavel atribuirá o surgimento da corrupção à perda da atuação política dos membros da cidade. Importante destacar que ele não defendeu uma república composta única e exclusivamente pelas camadas populares, mas a porosidade das instituições para que os cidadãos pudessem dar desafogo aos seus desejos, às suas reivindicações. Por outro lado, essas mesmas instituições já deveriam prever o surgimento da disputa política, ao menos entre os dois grandes grupos políticos - os pobres e os grandes. Sua função seria disciplinar e regular as contendas, não permitindo que elas resultassem em lutas violentas. Como assinalaram Sasso (1967) e Martins (2007), Maquiavel rejeita a disputa violenta, que implica em derramamento de sangue. $\mathrm{O}$ conflito político deve existir, mas tem que ser não-violento. Para ele, essa fronteira distinguiu a Roma republicana da república florentina 
de seu tempo exatamente pelo fato daquela possuir ordenamentos capazes de canalizar os conflitos.

Esse rápido percurso por alguns autores clássicos do pensamento político republicano mostra-nos o quanto a preocupação com a inclusão-exclusão nas esferas decisórias, com a maior ou menor porosidade das instituições, não apenas esteve nos centros das atenções, como também demarcou clivagens importantes nesse campo. Assim, se os autores republicanos, de forma geral, sempre manifestaram preocupação com a forte identificação dos indivíduos com os valores comuns, entendendo-a como fundamento para a ação política, por outro lado, tal fundamento, no interior do que se considera republicanismo, pôde adquirir conteúdos e resultar em horizontes de sociedade muito distintos, caso se leve em conta as discordâncias internas a esse campo sobre o papel atribuído ao conflito político e sobre a maneira como as instituições devem se portar diante dele. Ou seja, aquele fundamento pode resultar em propostas nada, pouco ou muito abertas ao reconhecimento da legitimidade das diferenças e das disputas políticas dependendo de como se aborda a relação entre a valorização do sentido de pertença a um coletivo e a definição de quem tem direito, e sob que condições, a se pronunciar e deliberar sobre esse mesmo coletivo.

Desse ponto de vista, as preocupações de Maquiavel com a vitalidade e a porosidade das instituições políticas e a sua consideração do papel dos conflitos para garanti-las circunscrevem, no interior da reflexão sobre as repúblicas, uma particular abordagem para aquela relação ${ }^{6}$. Nos seus termos, pode-se dizer que, se um dos elementos distintos da república é sua preocupação com o "bem-comum”, esse não é predeterminado ou estático, mas, ao contrário, é resultado das tensões e conflitos que atravessam e constituem a sociedade. Essa abordagem, como se percebe, resulta em propostas menos exigentes de cidadania naquilo que ela pressupõe como condição para a participação política.

\footnotetext{
6 A importância deste modelo de republicanismo e o seu vigor teórico para o debate contemporâneo foi analisado por Baccelli (2003).
}

O deslocamento da excelência da cidadania do centro de um modelo ideal de república define significativas diferenças entre a matriz de um republicanismo aristocrático e de um popular, demarcando as preocupações de fundo que embasam cada um dos modelos. No primeiro, a defesa da excelência da cidadania está fortemente associada à preocupação com a coesão social (pax socialis) e com o consenso. No segundo, ao deslocamento da centralidade daquele elemento subjaz uma preocupação fundamental com a porosidade das instituições republicanas.

Como pretendemos mostrar no próximo item, as críticas endereçadas por algumas feministas aos autores comunitaristas e aos teóricos do modelo deliberativo de democracia - quanto à reprodução de uma visão homogênea de sociedade, à dificuldade de lidar com o conflito de interesses e à desconsideração das desigualdades concretas permitem-nos sugerir as insatisfações que elas nutrem em relação às preocupações características da vertente aristocrática, na mesma medida em que nos permitem apontar suas importantes conexões com as preocupações da vertente popular. Mais além, ao elaborar um ponto de vista peculiar para compreender as relações entre os interesses particulares, o debate público e a construção de entendimentos, algumas feministas têm enriquecido e atualizado a vertente popular republicana mediante os complexos desafios que as democracias contemporâneas têm de enfrentar.

\section{PELA INCLUSÃO DAS DEMANDAS POR JUSTIÇA NA ESFERA PÚBLICA}

No que diz respeito às concepções liberais e republicanas das relações entre público e privado e suas consequências para o entendimento da liberdade individual, Joan Landes assim detectou a incômoda posição das feministas frente àquelas correntes: "The opposition between public and private is a distinguishing feature of both liberal and republican political argument, yet they offer practically opposing assessments of these two core terms. Liberals associate privacy with freedom: they value the private sphere and defend the individual's right to privacy against interference by other persons or the state. In contrast, republicans regard the private, which they associate with the body and its needs, as pertaining to those things that ought to be hidden from view. In turn, they associate the public with freedom, or acting in concert with others on behalf of the common good. [...] Feminism does 
not map comfortably onto either of these traditions, though, like republicans, feminists value public participation and, like liberals, they see the need to expand the contents of personal freedom"7 (LANDES, 1998, p. 2).

As feministas vêem-se, portanto, diante da difícil tarefa de equacionar aqueles incômodos de tal modo a elaborar uma defesa da esfera pública, própria da perspectiva republicana, sem abrir mão de atribuir legitimidade ao interesse particular nas suas demandas por liberdade, princípio geralmente mais associado ao liberalismo. Elas recusam o pressuposto liberal que assume os indivíduos como a unidade básica da vida democrática. Alegam que a ele subjaz uma concepção abstrata e androcêntrica de cidadão, que confina as mulheres a uma existência privada, na mesma medida em que camufla as desigualdades concretas às quais elas estão submetidas na sociedade e que, num círculo vicioso, perpetuam sua ausência ou precária presença na vida pública. Assim, a defesa da esfera pública interessa às feministas porque permite endereçar críticas à igualdade abstrata do liberalismo que retira as desigualdades do terreno propriamente político e, portanto, das preocupações afeitas à vida em comum. A concepção liberal que restringe a política à mera agregação de preferências individuais não serve a um ideal político que visa trazer para o debate público as estruturas e as relações desiguais e hierárquicas historicamente construídas sob os mitos universais do indivíduo soberano e racional.

Pelos mesmos motivos, as feministas não podem aderir a uma proposta que conceba os interesses particulares e a reivindicação de liberdades individuais como intrusos indesejados da esfera

\footnotetext{
7 “A oposição entre público e privado é um aspecto distintivo tanto do argumento republicano e como do liberal, ainda assim eles oferecem avaliações praticamente opostas daqueles dois termos centrais. Os liberais associam privacidade com liberdade: eles valorizam a esfera privada e defendem o direito do indivíduo à privacidade contra a interferência de outras pessoas ou do Estado. Em contraste, os republicanos tratam o privado, o qual associam com o corpo e suas necessidades, como pertencendo àquelas coisas que devem ser escondidas da vista. Ao contrário, eles associam público à liberdade, ou ao agir em conjunto em nome do bem-comum. [...] O feminismo não se encaixa confortavelmente em nenhuma dessas tradições, ainda que, como os republicanos, as feministas valorizam a participação pública e, como os liberais, vêem a necessidade de expandir os conteúdos da liberdade pessoal”.
}

pública. Nessa perspectiva, não está meramente em jogo a preocupação em proteger o indivíduo entendido como célula básica e apartada da sociedade, mas uma preocupação quanto à contínua exclusão de determinados interesses na esfera pública em nome de uma suposta unidade, coesão e "bem comum". Para Phillips, o próprio reconhecimento de que temos direito à liberdade individual abre possibilidades para a compreensão de que muitas das subordinações experimentadas não são fenômenos restritamente individuais, mas coletivos. A percepção da existência de um interesse próprio, particular, é fundamental, como ela assinala, para o questionamento das ficções de unidade construídas sob os ideais pretensamente universais. Procurando traduzir o dilema que resulta dessas considerações, a mesma autora faz a pergunta: “¿cómo conservar una perspectiva de seres humanos que trabajan conjunta $y$ democráticamente para lograr sus anhelos comunes sin caer, al mismo tiempo, en la complacencia que ignora la existencia de desigualdades sistemáticas entre grupos?” (PHILLIPS, 1996, p. 95).

O diálogo crítico de algumas feministas com os comunitaristas e com os teóricos da democracia deliberativa expressa as tentativas de equacionar o desafio formulado por Phillips em termos de reter determinados princípios republicanos, mas, ao mesmo tempo, rejeitar seus possíveis desdobramentos de negação da legitimidade de interesses específicos na esfera pública, o que perpetuaria, nessa óptica, desigualdades e exclusões. $\mathrm{O}$ que nos interessa mostrar, então, é que suas críticas repudiam o núcleo da vertente republicana aristocrática: a unidade do corpo político e o consenso. Do mesmo modo, suas propostas revelam importantes pontos de aproximação com a vertente republicana popular.

Como exemplo, o diálogo crítico de Marilyn Friedman (1996) com as abordagens comunitaristas de Alasdair MacIntyre e de Michael Sandel expressam os incômodos feministas em relação às formulações que, a seu ver, tenderiam a obscurecer a diversidade da sociedade e, como conseqüência, a deslegitimar determinadas demandas. Para compreender tais críticas na sua conexão com o desafio formulado por Phillips, é importante mencionar que, em primeiro lugar, Friedman salienta uma importante convergência entre a perspectiva comunitária daqueles autores e a feminista: em contraponto ao pressuposto liberal, as duas partem de uma concepção holista, 
que compreende a identidade e a natureza dos indivíduos a partir das relações sociais nas quais eles estão inseridos. De acordo com ela: "[...] los 'nuevos comunitaristas' [...] también han reaccionado críticamente a diferentes aspectos del pensamiento liberal moderno, incluyendo el individualismo abstracto, el egoísmo racional y la concepción instrumental de las relaciones sociales. El yo, o el sujeto, comunitario, no es tampoco un átomo social, sino un ser constituido y definido por sus vínculos, incluyendo las especificidades de sus relaciones sociales, sus vínculos comunitarios y su contexto histórico. Su identidad no puede abstraerse de la comunidad o de las relaciones sociales" (idem, p. 150).

Friedman expõe, assim, um importante ponto de contato entre feminismo e republicanismo naquilo que diz respeito ao contraste com a perspectiva liberal, na qual os indivíduos, independentemente de inserções sociais, formulam interesses próprios e acordos para a vida em sociedade. Esse foi um dos focos das críticas de Michael Sandel a John Rawls naquele trabalho que foi considerado um marco no debate entre comunistaristas e liberais (SANDEL, 1984). Nesse trabalho, Sandel cunhou uma expressão de difícil tradução em português para caracterizar o indivíduo projetado por Rawls: o "eu desimpedido", ou seja, um indivíduo abstrato, que seria capaz de formular seus interesses apartados de contextos sociais e de aceitar como legítimas, na visão de Sandel contraditoriamente, determinadas obrigações visando à promoção de justiça.

Assim, como também analisaram Benhabib e Cornell (1987), seja por apoiarem-se numa teoria que afirma a dimensão constitutiva social e cultural dos papéis de gênero, seja por apoiarem-se numa teoria psicanalítica da constituição do gênero, as críticas feministas e comunitaristas convergem em relação ao "eu desimpedido". Contudo, para Friedman, os comunitaristas tomam como ponto de partida uma concepção fortemente homogênea de sociedade, tendendo a naturalizar o vínculo do indivíduo com aquela e a dotá-lo de uma autoridade metafísica que não deixa espaço para que seus possíveis elementos opressores sejam questionados. Segundo ela, uma teoria que afirma a posição moral inquestionada de uma determinada comunidade, não leva em conta que os indivíduos são constituídos pelos seus vínculos com uma variedade de "comunidades". Note-se que os argumentos de Friedman sobre a perspec- tiva comunitarista tocam, assim, em preocupações que já haviam sido levantas por Fraser (1993) a respeito das análises de Habermas sobre a constituição da esfera pública burguesa, mencionadas anteriormente. Considerando tais desconfortos, Friedman assinalou: "En nuestra sociedad heterogénea, podemos encontrarnos a nosotras mismas insertas en diversas comunidades a la vez. Además, algunas relaciones compiten entre sí y otras proporcionan perspectivas desde las que otras relaciones parecen amenazantes o peligrosas para uno/a mismo/a, o bien para la propria integridad o el proprio bienestar. En tal caso, simples fórmulas acerca del valor de la comunidad no sirven en modo alguno de guía. El problema no radica simplesmente en apreciar la comunidad per se, sino más bien en reconciliar las exigencias conflictivas, las demandas y las influencias definidoras de la identidad de la variedad de comunidades de las que forma parte una persona" (FRIEDMAN, 1996, p. 156-157).

Do mesmo modo, Benhabid e Cornell afirmaram que, para a perspectiva feminista, não é suficiente reconhecer que o "eu" é sempre "situado", pois, para os comunistaristas, os sujeitos aparecem subsumidos de tal forma à sua persona social e comunal que não se deixa espaço para o reconhecimento de legitimidade a suas reivindicações por autonomia. Ou seja, as abordagens comunitaristas não permitem vislumbrar aquilo que é central para as feministas: a renegociação de nossas identidades em face de contextos sociais opressores.

Essas críticas mostram as insatisfações feministas com as formulações que lhes parecem conferir estatuto de centralidade à identificação do indivíduo com o corpo político e sua coesão, típicas da vertente republicana aristocrática. Quando tais preocupações assumem estatuto de primazia na construção de análises, elas resultam em dificuldades para incluir aquilo que é fundamental na óptica feminista: as clivagens constitutivas da sociedade naquilo que elas dizem respeito às exigências por justiça ${ }^{8}$. Desse ponto de vista, aquelas

\footnotetext{
8 Aqui se faz necessário lembrar que Charles Taylor (2000), também associado ao republicanismo comunitarista, propõe-se a enfrentar de maneira mais incisiva o reconhecimento das diferenças. Inclusive, assumindo a perspectiva de Sandel, ele formula respostas aos argumentos que acusam a este de não reconhecer as diferenças e o pluralismo das sociedades contemporâneas.
} 
exigências requerem formulações que levem em conta o problema das desigualdades concretas experimentadas.

O estatuto de importância adquirido pela preocupação com as desigualdades tem colocado no foco de muitas análises feministas o problema das formas de organização e composição das esferas decisórias. E esse é um ponto importante do qual originam-se muitas das críticas feministas às formulações correntes. Como notou Phillips (1995), a teoria política contemporânea tem preocupadose mais com o problema de definir a justeza do conteúdo das decisões do que com os processos por meio das quais elas são alcançadas e, assim, não aborda ou confere pouca importância às relações de poder que embasam os arranjos decisórios. A ausência desse problema na teoria política resulta, como ela parece sugerir, na construção de modelos que postulam a possibilidade de tomadas de decisões imparciais a partir de algum tipo de ocultação das posições concretas dos atores que "sentam à mesa de negociação". A preocupação das feministas com a porosidade das instituições políticas tem íntima relação com essa compreensão de que as diferenças que constituem os sujeitos devem ser reconhecidas, antes de neutralizadas, pelas propostas que visem justiça. Nisto, enxergamos importantes pontos de aproximação com a vertente republicana popular, que não apenas assume o conflito como dimensão constitutiva da esfera pública, como o percebe fonte da vitalidade e da renovação da vida política.

Interessada no problema dos arranjos decisórios, Iris Marion Young defendeu a pluralização das formas de representação. Para ela, a defesa da representação por grupos nas esferas decisórias fundamenta-se no reconhecimento de que determinados grupos - quanto ao gênero, classe e etnia - estão em posições estruturais desvantajosas na sociedade e, para conseguir chegar às esferas decisórias, precisam de incentivos particulares. Respondendo as acusações de que estaria supondo que os membros de um mesmo grupo tenham interesses homogêneos, Young argumentou que não se trata de essencializar identidades, mas de admitir que os indivíduos que estão numa mesma posição estrutural na sociedade compartilham de determinados pontos de vistas e que aqueles historicamente relegados precisam ser levados em conta para que as decisões públicas aproximem-se de um ideal de justiça (YOUNG, $2006)^{9}$. Nessa perspectiva, as posições estruturais dos indivíduos na sociedade define-os como grupo na medida em que lhes possibilitam compartilhar de experiências determinadas. Mas não produzem interesses automaticamente partilhados, apenas pontos de vistas tendencialmente comuns sobre a sociedade. Isso porque a compreensão dos indivíduos a respeito de sua posição faz-se a partir dos contextos específicos nos quais eles estão inseridos. Além disso, os indivíduos estão multiplamente posicionados na sociedade e podem, de acordo com sua experiência e contexto, mover-se de variadas formas, produzindo compreensões ambíguas, contraditórias ou mais completas sobre sua condição.

Essas formulações têm recebido várias críticas. As que nos interessam aqui são aquelas que tocam na pretensão de Young de combinar o reconhecimento das diferenças com o ideal, tipicamente republicano, de discussão e deliberação pública. Cynthia Ward, por exemplo, argumenta que a defesa da representação de grupo compromete a defesa simultânea da solidariedade e da coesão social, princípios caros ao republicanismo cívico (PHILLIPS, 1995). Na mesma direção, Miller (2002) afirma que Young não resolve satisfatoriamente o problema de combinar a possibilidade do consenso com a explosão dos conflitos que sua proposta de reconhecimento das diferenças e representação de grupos traz para a esfera pública.

De fato, a preocupação de Young com a inclusão de grupos oprimidos e subordinados na esfera pública desloca o problema do consenso, da imparcialidade e da coesão social do centro de sua reflexão. Mas é fundamental notar que tais deslocamentos permitem-na ter expectativas em relação ao processo e aos resultados das deliberações públicas bem diferentes daquelas nutridas,

\footnotetext{
9 Segundo Young, "[...] what constitutes a social group is not internal to the attributes and self-understanding of its members. Rather, what makes the group a group is the relation in which it stands to others" ("[...] o que constitui o grupo social não é interno aos atributos e ao auto-entendimento de seus membros. Em vez disso, o que faz do grupo um grupo é a relação na qual ele posiciona-se em relação a outros") (YOUNG, 1997, p. 389). Essa abordagem relacional distingue Young de outras perspectivas que são baseadas na idéia de que os grupos têm identidades fixas (SQUIRES, 2001).
} 
de acordo com sua avaliação, pelo modelo deliberativo de democracia, expectativas que, de algum modo, encontram-se nas críticas de Ward e Miller sobre a fragilidade de combinar explosão de conflitos e deliberação pública.

Como primeiro ponto, é importante lembrar que para Young, ao contrário de oferecerem obstáculos instransponíveis para o diálogo público, as múltiplas posições experimentadas pelos indivíduos na estrutura social disponibilizam-lhes recursos para distanciarem-se de suas compreensões particulares e comunicarem-se com os outros (YOUNG, 2001). Nessa medida, em uma democracia comunicativa, como ela denomina, a diferença é, antes, um recurso que favorece a comunicação. As críticas de Young aos teóricos da democracia deliberativa tocam exatamente nesse ponto. Ao incorporar o problema da composição dos arranjos decisórios em suas reflexões, defendendo a garantia de representação específica para os grupos oprimidos na sociedade, ela questiona os teóricos deliberativos por sua pressuposição de que o debate racional poderia equalizar as desigualdades concretas pela suspensão das diferenças. Ela percebe problemas na maneira como aqueles teóricos elaboram as relações entre demandas específicas, debate público e entendimento.

$\mathrm{Na}$ avaliação de Young, os deliberativos não deixam claras quais mudanças o debate público poderia promover nos interesses específicos e particulares presentes. Eles trabalham com a idéia de que a função daquele debate, realizado por meio do discurso racional, é restaurar ou chegar a unidades, de modo que as diferenças sejam transcendidas e o "bem-comum" prevaleça. Ela afirma, então, que, se a função de debate é restaurar unidades, ele apenas apela para o que já era compartilhado e, portanto, não provoca efetivamente mudanças nos interesses ou visões particulares. Para os que, reconhecendo esse problema, postulam que o objetivo do debate é produzir a unidade, ela argumenta que isso pode perpetuar exclusões e injustiças. Aqueles que estão em situação de desvantagem material ou cultural não têm as mesmas condições e os mesmos recursos daqueles que estão em posição privilegiada para formular, via argumento racional, seus interesses em termos de um "bem-comum". Nesse caso, "pedese aos menos privilegiados que deixem de lado a expressão de suas experiências em nome de um bem comum que pode ser desfavorável a eles" (idem, p. 376). Essa crítica chama a atenção, portanto, para o fato de que o "lugar de fala" dos participantes, como interpretou Miguel (2005), não é um lugar neutro, ao contrário, é demarcado por assimetrias expressas na distribuição desigual de recursos simbólicos e materiais. Afinal, o próprio expediente legitimador da fala para os deliberativos, o discurso racional, pressupõe, na perspectiva de Young, que exista um critério neutro de tradução de demandas, o que é ilusório e excludente, pois há outras formas de comunicação que são mais acessíveis para determinados grupos que o argumento racional e que precisam ser reconhecidas válidas no debate.

Para ela, os deliberativos lançam muitas exigências para a idéia de unidade e para a de "bemcomum". Por suposto, algum grau de unidade é necessário para que haja o debate público, mas ele deve ser sutil, restringindo-se (a) ao reconhecimento de que há uma interdependência entre os participantes, ou seja, de que as condições de realização de suas atividades e ambições estejam mutuamente condicionadas; (b) ao comprometimento com o respeito mútuo, que deve expressar-se em garantias formais a todos para expressarem seus pontos de vista e (c) ao acordo quanto aos procedimentos e regras que devem reger o debate - que, como já mencionamos, deveriam ser mais flexíveis para incluir como legítimos outros expedientes de expressão de demandas para além do argumento crítico. Eis aqui um elemento central do projeto crítico de Iris Young. Segundo ela, expedientes de expressão como, por exemplo, a saudação, a retórica e a narração foram deslegitimados por boa parte do pensamento político. Este optou pela ênfase praticamente restrita no argumento crítico, racional, pressupondo uma separação entre razão e sensibilidade, entre mente e corpo, que desqualifica os segundos pólos desses pares e seus falantes.

Em relação ao "bem-comum”, analisa ela, os teóricos deliberativos entendem que seria o resultado bem sucedido do debate como expressão da mútua identificação entre os participantes, como se as diferenças pudessem, pela razão, ser assimiladas uma pelas outras, de tal maneira que fosse possível encontrar "um ponto neutro", que estivesse acima de todos. Entretanto, como já se mencionou, para ela, a razão não é um critério neutro de comunicação e nem o encontro de um "ponto neutro" - que para ela é ilusório sempre - 
deve ser o objetivo do debate público, já que as diferenças não podem ser reduzidas a um "bemcomum". O debate público tem, portanto, a função de fazer que os participantes tirem lições da comunicação de uma experiência diferente da sua. Desse modo, entender o outro significa simplesmente que "houve uma expressão bem sucedida de experiências e perspectivas que possibilitou às outras posições uma compreensão daquelas diferentes das suas [...] Parte do que terão entendido é que há coisas além da experiência e da perspectiva que transcendem sua própria subjetividade" (YOUNG, 2001, p. 378). Ou seja, não se abandona as próprias expectativas, mas pode-se, num processo de debate bem sucedido, compreender algo "sobre a maneira em que propostas e reivindicações afetam os que estão diferentemente situados" (ibidem).

Dessa forma, os participantes constroem uma visão mais abrangente das questões em jogo e do modo como elas podem afetar os distintos grupos e interesses, o que proporciona mais objetividade e sabedoria para a tomada de decisões. Noutras palavras, uma comunicação bem sucedida resulta em maiores chances para que as decisões produzam resultados justos, sem que se apele para um suposto ponto neutro com o qual todos os interesses possam identificar-se. Afinal, a imparcialidade não tem compromisso com a justiça, mas com a suposição de que é possível chegar-se a um ponto de vista que fica a parte de qualquer interesse e desejo (YOUNG, 1987). Nutrir a idéia de que isso seja possível significa correr sempre o risco de excluir determinadas demandas sob o argumento de que elas expressariam pontos de vistas parciais e, como conseqüência, repor como condição de legitimidade de fala e expressão a virtude de estar-se, supostamente, acima de paixões e desejos. Por isso, o mais importante para essa autora é garantir a porosidade das instituições, sem que nenhuma demanda tenha, a priori, negada sua legitimidade de expressão, sendo forçada, assim, a permanecer numa existência privada.

Desse modo, as insatisfações de Young quanto aos teóricos deliberativos podem ser aqui também conectadas às suas insatisfações com o conjunto de preocupação que constitui a vertente republicana aristocrática, que prima por cidadãos que virtuosamente despir-se-iam de seus interesses particulares para encontrar um "bem-comum" imparcial, expressão e condição de existência do corpo político coeso. E, por outro lado, ao entender que o debate público tem como meta primordial não necessariamente o consenso como expressão de uma identificação mútua entre os participantes, mas o reconhecimento de suas diferenças num contexto de confronto com os poderes estabelecidos, ela aproxima-se do conjunto de preocupação que define a vertente republicana popular. Young elabora um ponto de vista que procura combinar a legitimidade dos interesses particulares com o ideal do debate público e as suas possibilidades de gerar entendimentos. Nessa medida, se o conjunto das críticas feministas aqui apresentado revela sua divergência diante da vertente republicana aristocrática, as reflexões de Young contribuem para revigorar a vertente popular republicana naquilo que exige a consideração da pluralidade das sociedades contemporâneas e as demandas por justiça.

\section{CONCLUSÕES}

Nossa proposta de analisar as relações entre feminismo e republicanismo levou-nos a abordar este último a partir de questões que, embora presentes na reflexão de autores clássicos, não são muito consideradas pelo debate contemporâneo, cujo cerne está no tema da liberdade. Não se trata de negar a importância que esse tema possui para o pensamento republicano, nem de desconsiderar a riqueza produzida pelas discussões a seu respeito. Entretanto, analisar o republicanismo tendo por foco os arranjos decisórios permitiu-nos trazer para o centro das atenções o lugar destinado aos conflitos políticos para as distintas vertentes que o constituem.

É, sobretudo, desta perspectiva e dos desdobramentos que dela resultam que podemos considerar a contribuição das feministas para o debate contemporâneo sobre a democracia. É certo que a pluralidade impõe-se como problema para qualquer reflexão atual que tome a democracia como objeto de interesse, como também a diferença tem colocado-se como um problema central em várias das formulações correntes. Contudo, as feministas, em particular, tiveram o mérito de deixarnos em alerta quanto às propostas nas quais os conflitos políticos podem aparecer como algo a ser superado, como se não fossem intrínsecos à vida e com os quais temos que lidar, sob condições de projetarmos alternativas que reproduzem exclusões e injustiças. Essa é a chave para compreender os vínculos entre as propostas feminis- 
tas e a vertente popular republicana que tem em Maquiavel seu mais significativo exemplar.

É necessário reconhecer que a contribuição das feministas para a teoria política fez-nos perceber as muitas limitações presentes nas tradições de pensamento ocidental, as quais continuamente conceberam a cidadania e a esfera pública a partir de um olhar de gênero situado. Nele, as mulheres foram relegadas à condição privada de existência. $\mathrm{O}$ varão, muitas vezes, o varão militar, constituiuse na referência por excelência do sujeito político. Maquiavel, entre muitos outros autores, reproduziu tal concepção. Não se trata aqui de isentálo, nem de restringir as propostas feministas ao que ele, no século XVI, estava preconizando para sua sociedade. O que se desejou, entretanto, foi mostrar que as reflexões daquele renascentista oferecem-nos pontos de partida para a elaboração de propostas republicanas que efetivamente as- sumam o conflito como elemento central da vida comum. Nesse aspecto, podemos deslocar os critérios de excelência do centro de uma definição de cidadania, para além dos próprios critérios que aquele autor havia mantido.

É nessa perspectiva que podemos aproximar as feministas da vertente republicana popular e assinalar que seu trabalho crítico não se restringe a contribuir para o aprofundamento das lutas feministas. Ao desconstruírem as referências sobre as quais a idéia de sujeito político foi elaborada, elas disponibilizam instrumentos conceituais e apresentam uma série de possibilidades para que outros grupos questionem as exclusões e as opressões por eles experimentadas. Ao conectarem o problema das desigualdades com o da porosidade das instituições políticas, elas ajudam-nos a elaborar um ideal de esfera pública que esteja continuamente aberta para as demandas por justiça.

Carla Cecília Rodrigues Almeida (carlaalm@uol.com.br) é Doutora em Ciências Sociais pela Universidade Estadual de Campinas (Unicamp) e Professora da Universidade Estadual de Maringá (UEM).

José Antonio Martins (zeamartins@gmail.com) é Doutor em Filosofia pela Universidade de São Paulo (USP) e Professor da Universidade Estadual de Maringá (UEM).

\section{REFERÊNCIAS BIBLIOGRÁFICAS}

ARISTÓTELES. 1998. Politica. Lisboa: Vega.

BENHABIB, S. \& CORNELL, D. 1987. Além da política de gênero. In: BENHABIB, S. \& CORNELL, D. (orgs.). Feminismo como crítica da modernidade. Releitura dos pensadores contemporâneos do ponto de vista da mulher. Rio de Janeiro: Rosa dos Tempos.

BERLIN, I. 2002. Dois conceitos de liberdade. In: HARDY, H. \& HAUSHEER, R. (orgs.). Isaiah Berlin: estudos sobre a humanidade. São Paulo: Companhia das Letras.

BLYTHE, J. 2005. Le gouvernement ideal et la constitution mixte au Moyen Âge. Paris: CERF.

CRISTI, R. 2003. Participación, representación y republicanismo. Anuario Filosófico, Navarra (Espanha), v. 36, n. 1, p. 53-81. Disponível em: http:/dspace.unav.es/dspace/bitstream/ 10171/87/8/4.\%20PARTICIPACI\%C3\% 93N, \%20REPRESENTACI\%C3\%93N\% 20Y\%20REPUBLICANISMO,\%20RENATO $\%$ 20CRISTI. pdf. Acesso em: 1.maio.2010.
DIETZ, M. G. 1999. O contexto é o que conta: feminismo e teorias da cidadania. Debate $\mathrm{Fe}$ minista, São Paulo, n. especial, p. 3-28.

ELIAS, M. L. G. G. R. 2008. Democracia e participação política no novo republicanismo: um estudo sobre o pensamento de Philip Pettit. Florianópolis. Dissertação (Mestrado em Sociologia Política). Universidade Federal de Santa Catarina.

FRASER, N. 1993. Rethinking the Public Sphere: a Contribution to the Actually Existing Democracy. In: ROBBINS, B. (ed.). The Phantom Sphere. Minnesotta: University of Minnesotta.

FRIEDMAN, M. 1996. El feminismo y la concepción moderna de la amistad: dislocando la comunidad. In: CASTELLS, C. (org.). Perspectivas feministas en teoría política. Barcelona: Paidós.

GILBERT, F. 1977. Machiavelli il suo tempo. Bologna: Il Mulino. 
HIRSCHMAN, A. O. 1995. Conflitos sociais como pilares da sociedade de mercado democrática. Novos Estudos, São Paulo, n. 42, p. $33-44$.

LANDES, J. 1998. Introduction. In: (ed.). Feminism, the Public, and the Private. Oxford: Oxford University.

LEPORE, E. 1954. Il princeps ciceroniano e gli ideali politici della tarda republica. Napoli: Istituto Italiano per gli Studi Storici.

MACHIAVELLI, N. 1984. Discorsi sopra la prima deca di Tito Livio. Milano: Rizzoli.

MARTINS, J. A. 2007. Os fundamentos da república e sua corrupção nos Discursos de Maquiavel. São Paulo. Tese (Doutorado em Filosofia). Universidade de São Paulo.

MIGUEL, L. F. 2005. Teoria democrática atual: esboço de mapeamento. BIB, São Paulo, n. 59 , p. 5-42.

MILLER, D. 2002. Ciudadanía y pluralismo. Lima: Instituto de Estudios Peruanos. Disponível em: http://www.cholonautas.edu.pe/modulo/upload/miller.pdf. Acesso em: 1.maio.2010.

NASH, K. 2001. Patriarchy. In: CLARKE, P. B. \& FOWERAKER, J. (eds.). Encyclopedia of Democratic Thought. London: Routledge.

NICOLET, C. 1973. Polybe et les institutions romanes. In: Vandouvres. Entretiens. T. XX. Genève:

OVEJERO, F.; MARTÍ, J. L. \& GARGARELLA, R. 2004. Introducción. In: OVEJERO, F.; MARTÍ, J. L. \& GARGARELLA, R. (orgs.). Nuevas ideas republicanas: autogobierno y libertad. Barcelona: Paidós.

PATEMAN, C. 1992. Participação e teoria democrática. Rio de Janeiro: Paz e Terra.

PETTIT, P. 1999. Republicanismo: una teoría sobre la libertad y el gobierno. $2^{\mathrm{a}}$ ed. Barcelona: Paidós.

2004. Liberalismo y republicanismo. In OVEJERO, F.; MARTÍ, J. L. \& GARGARELLA, R. (orgs.). Nuevas ideas republicanas: autogobierno y libertad. Barcelona: Paidós.
PHILLIPS, A. 1995. The Politics of Presence. Oxford: Oxford University.

1996. Deben las feministas abandonar la democracia liberal? In: CASTELLS, C. (org.). Perspectivas feministas en teoría política. Barcelona: Paidós.

2000. Which Equalities Matter? $2^{\text {nd }}$ ed. Cambridge: Polity.

2004. Feminismo y republicanismo: es ésta una alianza plausible? In: OVEJERO, F.; MARTÍ, J. L. \& GARGARELLA, R. (orgs.). Nuevas ideas republicanas: autogobierno $\mathrm{y}$ libertad. Barcelona: Paidós.

POCOCK, J. G. A. 1980. Il momento machiavelliano. Bologna: Il Mulino.

POLÍBIO. 2002. Storie. Libri V-VI. V. III. Milano: Rizzoli.

SANDEL, M. 1984. The Procedural Republic and Unencumbered Self. Political Theory, London, v. 12, n. 1, p. 81-96, Feb. Disponível em: http:/ /www.polsci.wvu.edu/Faculty/Michelbach/ sandel.pdf. Acesso em: 1.maio.2010.

SASSO, G. 1967. Studi su Machiavelli. Napoli: Morano.

SILVA, R. V. 2008. Liberdade e lei no neorepublicanismo de Skinner e Pettit. Lua Nova, São Paulo, n. 74, p. 151-194. Disponível em: http://www.scielo.br/pdf/ln/n74/07.pdf. Acesso em: 1.maio.2010.

SKINNER, Q. 2004. Las paradojas de la libertad política. In: OVEJERO, F.; MARTÍ, J. L. \& GARGARELLA, R. (orgs.). Nuevas ideas republicanas: autogobierno y libertad. Barcelona: Paidós.

SQUIRES, J. 2001. Representing Groups, Deconstructing Identities. Feminist Theory, London, v. 2, n. 1, p. 1-27.

TAYLOR, C. 2000. Argumentos filosóficos. São Paulo: Loyola.

YOUNG, I. M. 1987. A imparcialidade e o público cívico: algumas implicações feministas da teoria moral e política. In: BENHABIB, S \& CORNELL, D. (orgs.). Feminismo como crítica da modernidade. Releitura dos pensadores contemporâneos do ponto de vista da mulher. Rio de Janeiro: Rosa dos Tempos. 
1997. Difference as a Resource for Democratic Communication. In: BOHMAN, J. \& REHG, W. (orgs.). Deliberative Democracy: Essays on Reason and Politics. Cambridge: MIT.

2001. Comunicação e o outro: além da democracia deliberativa. In: SOUZA, J. (org.). Democracia hoje. Novos desafios para a teoria democrática contemporânea. Brasília: UNB.
. 2006. Representação política, identidade e minorias. Lua Nova, São Paulo, n. 67, p. 139190. Disponível em: http://www.scielo.br/pdf/ ln/n67/a06n67.pdf/. Acesso em: 1.maio.2010.

ZERILLI, L. 2006. Feminist Theory and the Canon of Political Thought. In: DRYZEK, J. S.; HONIG, B. \& PHILLIPS, A. (eds.). The Oxford Handbook of Political Theory. Oxford: Oxford University. 


\section{FEMINISTS AND THE DIVERSITY OF REPUBLICAN ALTERNATIVES}

\section{Carla Cecília Rodrigues Almeida and José Antônio Martins}

This article analyzes the critical move of certain feminists toward republicanism and explores the hypothesis that such a move represents important points of contact with a current of popular republicanism. Based on classical authors and adopting specific criteria for looking at the constitutive diversity of republicanism, we seek a way to define this current and as well as the aristocratic one which serves as its counterpoint. Our hypothesis is based, on the one hand, on analysis of feminist critiques of certain current formulations which, to a greater or lesser extent, share the republican ideal that contemporary society must endow public life with renewed meaning. On the other hand, it draws from particular proposals that have been elaborated in order to appropriate this ideal. Our analysis then makes it possible to suggest that the concerns that characterize the popular republican current offer more promising sources for combining the ideal of a renewed public sphere with demands for justice. Through this focus, we emphasize feminist contributions to democratic theory.

KEYWORDS: feminist theory; popular republicanism; aristocratic republicanism; democratic theory. 


\section{LES FÉMINISTES ET LA DIVERSITÉ DES ALTERNATIVES RÉPUBLICAINES}

\section{Carla Cecília Rodrigues Almeida et José Antônio Martins}

L'article analyse l'approche critique de quelques féministes au républicanisme et explore l'hypothèse de que tel approche exprime des points de contact importants avec la branche républicaine populaire. En se basant sur des auteurs classiques et en adoptant un critère spécifique pour approcher la diversité constitutive du républicanisme, nous définissons les contours de la branche et de celle qui lui sert de contrepoint : la branche aristocratique. Notre hypothèse s'est basée d'un côté, sur l'analyse des critiques féministes à quelques formulations courantes qui, en certaine mesure, partagent l'idéal républicain de que la société contemporaine a besoin de créer un nouveau sens pour la vie publique. De l'autre côté, elle est basée sur les propositions qu'elles mêmes élaborent pour s'approprier de l'idéal. Cette analyse nous permet de suggérer que les préocupations qui caractérisent la branche républicaine populaire, offrent des sources plus prometeuses pour qu'on puisse combiner l'idéal de revitalisation de l'esphère publique avec les éxigences de justice. A partir de là, nous mettons en évidence les contributions que les féministes ont apporté à la théorie démocratique.

MOTS-CLES: théorie féministe; républicanisme populaire; républicanisme aristocratique; théorie démocratique. 